Biogeosciences Discuss., https://doi.org/10.5194/bg-2017-346

Manuscript under review for journal Biogeosciences

Discussion started: 20 September 2017

(c) Author(s) 2017. CC BY 4.0 License.

\title{
On the potential causes of the recent Pelagic Sargassum blooms events in the tropical North Atlantic Ocean
}

\author{
Sandrine Djakouré ${ }^{1,2,4}$, Moacyr Araujo ${ }^{2,3}$, Aubains Hounsou-Gbo ${ }^{2,3}$, Carlos Noriega ${ }^{2,3}$, and \\ Bernard Bourlès ${ }^{4}$ \\ ${ }^{1}$ Laboratoire de Physique de l'Atmosphère et de Mécanique des Fluides (LAPA-MF), UFR SSMT, Université Félix \\ Houphouët-Boigny, 22 BP 582 Abidjan 22, Côte d'Ivoire \\ ${ }^{2}$ Laboratório de Oceanografia Física Estuarina e Costeira (LOFEC), Departamento de Oceanografia da Universidade Federal \\ de Pernambuco (DOCEAN/UFPE), Recife, PE, Brazil \\ ${ }^{3}$ Brazilian Research Network on Global Climate Changes (Rede CLIMA), São José dos Campos, SP, Brazil \\ ${ }^{4}$ Laboratoire d'Études en Géophysique et Océanographie Spatiales (LEGOS), UMR 5566 CNES/CNRS/IRD/UPS, Plouzané, \\ France
}

Correspondence to: Sandrine Djakouré (agre.djakoure@ ird.fr)

\begin{abstract}
Since 2011, unprecedented and repetitive blooms and large mass strandings of the floating brown macroalgæ, Sargassum natans and Sargassum fluitans have been reported along the West Indies, the Caribbean, the Brazilian and the West Africa coasts. Recent studies have highlighted a new tank of Sargassum: the North Equatorial Recirculation Region of the Atlantic Ocean. This region is located off the northeast of Brazil, approximately between the equator and $10^{\circ} \mathrm{N}$ and from $50^{\circ} \mathrm{W}$

5 to $25^{\circ} \mathrm{W}$. The potential causes of these recent blooms and mass strandings are still poorly understood. Observational datasets and modelling outputs involving hydrological parameters and climate events are examined focusing on their potential feedback on the observed blooms and mass strandings. The results show that combined conditions have been in favor of these recent changes. High anomalously unprecedented positive sea surface temperature observed in the tropical Atlantic in 2010-2011 could have induced favorable temperature conditions for Sargassum blooms. These favorable conditions were then fed by additional continental nutrients inputs, principally from the Amazon River. These continental nutrients load are the consequences of deforestation, agroindustrial and urban activities in the Amazonian forest. The results also suggest that subsurface intake of nutrients from the equatorial upwelling could also contribute to the blooms of the Sargassum seaweed in the Atlantic Ocean but further studies are needed to confirm these additional inputs.
\end{abstract}

Key words: Pelagic Sargassum, North Equatorial Recirculation Region, Sea Surface Temperature, Amazon River, nutrients

\section{Introduction}

The Pelagic Sargassum are brown macroalgæ, which have been firstly documented in the North Atlantic Ocean by Christopher Columbus, from the Sargasso Sea off the East Coast of the United States. Mainly two species of the genus Sargassum live and float on the surface of the tropical Atlantic : the Sargassum natans (Linnaeus) Gaillon and the Sargassum fluitans (Børgesen) Børgesen (Butler et al., 1983; Butler and Stoner, 1984; Lapointe, 1995; Guiry and Guiry, 2011; Szèchy et al., 2012; Smetacek 
Biogeosciences Discuss., https://doi.org/10.5194/bg-2017-346

Manuscript under review for journal Biogeosciences

Discussion started: 20 September 2017

(c) Author(s) 2017. CC BY 4.0 License.

and Zingone, 2013; Sissini et al., 2017). The Pelagic Sargassum are also found in the northern Gulf of Mexico (Gower et al., 2006; Gower and King, 2011; Hu et al., 2016), $90 \%$ of Sargassum natans and $10 \%$ of the Sargassum fluitans (Hernandez, 2011).

Since 2011, large mass strandings of the floating Sargassum have been reported along the West Indies and the Caribbean coasts (Gower et al., 2013; Mazéas, 2014; Wang and Hu, 2017), the Brazilian coasts (Szèchy et al., 2012; Sissini et al., 2017) and the West Africa coasts (Smetacek and Zingone, 2013; Johnson et al., 2013; Oyesiku and Egunyomi, 2014; Sankaré et al., 2016). These massive strandings and their locations in the topical Atlantic are unprecedented, observed almost yearly from 2011 (Wang and $\mathrm{Hu}, 2016,2017$; Sissini et al., 2017) and have important consequences for the coastal and marine ecosystems, the water quality, the health of the population and the economic life. Such events indicate Sargassum recent changes in both spatial and temporal distributions in the tropical North Atlantic.

Gower et al. (2013) and Wang and Hu (2016) have highlighted a new tank of Sargassum in a region located off the northeast of Brazil, approximately between the equator and $10^{\circ} \mathrm{N}$ and from $50^{\circ} \mathrm{W}$ to $25^{\circ} \mathrm{W}$, called the North Equatorial Recirculation Region of the Atlantic Ocean (NERR, Fig. 1, bottom). During some year periods, the pelagic Sargassum are transported by the Atlantic currents system from the northern tropical Atlantic to the Caribbean and the West Indies, as well as to West Africa. Gower et al. (2013) have used remote sensing based on the Medium Resolution Imaging Spectrometer (MERIS) to describe the new Sargassum distributions in the Northern Atlantic Ocean, between 2002 and 2011. Large amounts of Sargassum natans or Sargassum fluitans have been detected in an area off North Brazil, which is centered at about $7^{\circ} \mathrm{N}, 45^{\circ} \mathrm{W}$ and extending from the Caribbean to Africa, from July to September 2011. Wang and Hu (2016) got similar results by using the Moderate Resolution Imaging Spectroradiometer (MODIS) alternative floating algae index (AFAI), over the Central West Atlantic region $\left(0^{\circ} \mathrm{N}-22^{\circ} \mathrm{N}, 63^{\circ} \mathrm{W}-38^{\circ} \mathrm{W}\right)$ and from 2000 to 2015 . Since 2011, only the year 2013 showed a minimal Sargassum coverage in the Central West Atlantic region. The maximum Sargassum coverage has been detected during 2015.

The causes of these recent blooms and mass strandings of Sargassum are not yet well apprehended. The knowledge about these changes is limited and several hypotheses have been put forward: anomalous nutrient inputs from the tropical Atlantic large rivers discharges (Amazon, Orinoco and Congo) but also by equatorial upwelling, African atmospheric dust, climate changes induced increasing of sea water temperature and/or ocean currents changes (Johnson et al., 2013; Goes et al., 2014; Franks et al., 2014; Oxenford et al., 2015; Guimberteau et al., 2016).

Free floating marine plants need the energy of the sun (light) and carbon dioxide and nutrients (nitrate, phosphate, iron) intakes for their growth (Ang, 2006; King, 2011; Sfriso and Facca, 2013; Xu et al., 2017). Gao and McKGao (1994) indicated that the most important parameters affecting macroalgæ, such as Sargassum production, are irradiance, temperature, nutrients and plankton grazing. Gao and Nakahara (1990) have demonstrated that the macroalgæ Sargassum horneri photosynthesis is correlated to the temporal changes in nitrate concentration and water temperature. Moreover, rapid water motion results in higher productivity of macroalgæ. Indeed, increasing current speed facilitates the uptake of nutrients by macroalgæ, even in seawater with low nutrient concentration (Gellenbeck and Chapman, 1986; Gao, 1991; Carpente et al., 1991; Gao and McKGao, 1994). Lapointe $(1986,1995)$ have also evinced the increased production of Sargassum natans and Sargassum fluitans by an extra addition of phosphate and nitrate. The Sargassum productivity was enhanced in the coastal waters by nutrient loads from 
Biogeosciences Discuss., https://doi.org/10.5194/bg-2017-346

Manuscript under review for journal Biogeosciences

Discussion started: 20 September 2017

(c) Author(s) 2017. CC BY 4.0 License.

land. Nevertheless, Sargassum natans is more nitrate than phosphate limited Lapointe (1995). Smetacek and Zingone (2013) have also observed that the increase of Sargassum natans and Sargassum fluitans is related to higher nutrients inputs from the Mississippi River in the Gulf of Mexico.

In addition to nutrients from rivers and equatorial upwelling, African atmospheric dust, the world's largest dust source 5 (Prospero et al., 2014), has been also proposed to be a potential cause for the recent Sargassum blooms in the tropical North Atlantic (Johnson et al., 2013; Franks et al., 2014; Oxenford et al., 2015). The African dust transport has been found to cause a significant degradation of soils while the re-sedimentation provides a supply of nutrients (iron, phosphate) to terrestrial ecosystems and an increase in fertility in the area of dust settlement, as observed for the Amazon forest (Swap et al., 1992; Scheuvens et al., 2013). Nevertheless, the amount of these nutrients inputs is significantly less than the one provided by tropical rivers and equatorial upwelling (Prospero et al., 2014; Yu and al., 2015). Furthermore, the African aerosol transport has decreased over the past two decades since the peak in the 1980s (Hsu et al., 2012; Chin et al., 2014). Using AVHRR satellite, Ridley et al. (2014) have observed a decreased of $10 \%$ per decade from 1982 to 2008. Evan et al. (2016) have also found a significant downward trend in African dust emission and transport related to an increase of the greenhouse gas concentrations over the twenty-first century. The results of Wang et al. (2012) suggest a possible explanation of this mechanism for the North Atlantic sea surface temperature (SST). Indeed, a warm (cold) North Atlantic SST produces a wet (dry) condition over Sahel which induces a low (high) concentration of dust in the tropical North Atlantic.

The blooms of Sargassum in the tropical Atlantic could also be due to a warmer SST associated with nutrient-enriched oceans, induced by the continental runoff in addition to urban and agro-industrial sources (Sissini et al., 2017). Nevertheless, these authors mentioned that alternative hypotheses need to be considered, for example for Sargassum originating from the Mexican coast, as there is no evidence of drift from north to south. These authors concluded that the Sargassum bloom events are still unknown and more information are required. It is therefore important to continue the investigation and to explore new tracks.

This paper focuses on the analysis of observations, model outputs of hydrological parameters and ocean conditions over the tropical Atlantic basin, in order to investigate climate variations, trends or events and their potential feedback on the recent Sargassum blooms and mass strandings. The following section describes the datasets and the methodology used for this study. In section 3 the major (main) results of this study are presented, before a discussion and a summary in the last section.

\section{Materials and methods}

To investigate the potential effects of climate variations and events on the recent occurrence of Sargassum blooms, interannual variability of oceanic and atmospheric state-variables have been analyzed.

\subsection{Sea Surface Temperature and wind stress data}

The monthly SST and wind stress data used herein are provided by the latest update of TropFlux (Air-Sea Fluxes for the Global Tropical Oceans), products from the ESSO-Indian National Centre for Ocean Information Services. This dataset is 
Biogeosciences Discuss., https://doi.org/10.5194/bg-2017-346

Manuscript under review for journal Biogeosciences

Discussion started: 20 September 2017

(c) Author(s) 2017. CC BY 4.0 License.

made available at http://www.incois.gov.in/tropflux datasets/data. TropFlux dataset is based upon the ECMWF Re-Analysis interim (ERA-I) and ISCCP (International Satellite Cloud Climatology Project) projects. Daily and monthly high-quality airsea fluxes, SST and wind stresses are produced by this project over the global tropical ocean belt $\left(30^{\circ} \mathrm{N}-30^{\circ} \mathrm{S}\right)$ and are available from 1979 to 2016 . These data are gridded at a $1^{\circ} \times 1^{\circ}$ resolution (Praveen Kumar et al., 2013).

\section{$5 \quad 2.2$ Climate indices}

Three climate indices are used : $(i)$ the Atlantic Multi-decadal Oscillation (AMO), which is based on the average anomalies of SST from the Kaplan SST dataset, in the North Atlantic basin over $0^{\circ}$ N-80 ${ }^{\circ} \mathrm{N}$ (Trenberth et al., 2017); (ii) the North Atlantic Oscillation (NAO) based upon the difference of normalized sea level pressure, between Lisbon (Portugal) and Reykjavik (Iceland) (Hurrell and for Atmospheric Research Staff, Eds) and (iii) the Atlantic Meridional Mode (AMM) index based upon the meridional variability of the NCEP SST in the tropical Atlantic (Chiang and Vimont, 2004), obtained from the National Oceanic and Atmospheric Administration (NOAA). These data are available from https://www.esrl.noaa.gov/psd/gcos wgsp/Timeseries/AMO/ for AMO index, from https://www.esrl.noaa.gov/psd/gcos wgsp/Timeseries/NAO/ for NAO index and from https://www.esrl.noaa.gov/psd/data/timeseries/monthly/AMM/ for AMM SST index.

\subsection{River discharges}

15 In order to evaluate rivers discharges and variability and their influence on the Sargassum blooms, the products from the French HYBAM "Geodynamical, hydrological and biogeochemical control of erosion/alteration and material transport in the Amazon, Orinoco and Congo basins" Environmental Research Observatory are used. South America data are managed by the Brazilian National Water Agency (ANA). All the dataset (daily and monthly) are freely available at http://www.ore-hybam.org/. The Amazon River discharge data, available from 1968 to 2016, have been extracted from the Obidos station at $01.92^{\circ} \mathrm{S}$ in latitude and $55.67^{\circ} \mathrm{W}$ in longitude. For the Orinoco River, we used data extracted at Ciudad Bolivar, located at $08.15^{\circ} \mathrm{N}$ in latitude and $63.54^{\circ} \mathrm{W}$ in longitude, from 2003 to 2016. The Congo River discharge data have been extracted from the Brazzaville station, at $4.26^{\circ} \mathrm{S}$ in latitude and $15.25^{\circ} \mathrm{E}$ in longitude, from 1990 to 2016.

\subsection{Nutrients load}

Due to the lack of sufficient in situ nutrients data, continental nutrients loads were estimated from statistical modelling outputs. Formulas (1)-(4) are applied for the fluxes of dissolved inorganic nitrogen (DIN) and dissolved inorganic phosphorus (DIP) from regression models, which were built using 165 water systems worldwide analysis, DIN and DIP information (Smith et al., 2003; Araujo et al., 2014). Note that the works of Smith et al. (2003) and Araujo et al. (2014) are an update analysis of the Meybeck's DIN and DIP estimates deduced from 30 large rivers (Meybeck, 1982; Meybeck and Ragu, 1997). The regression models used are based on the surface water systems runoffs and the population density. The interannual surface water systems 
Biogeosciences Discuss., https://doi.org/10.5194/bg-2017-346

Manuscript under review for journal Biogeosciences

Discussion started: 20 September 2017

(c) Author(s) 2017. CC BY 4.0 License.

runoffs are extracted from the ANA and the HYBAM data sets. The population density rates for the rivers basins were extracted from the five worldwide databases (refer to Smith et al. (2003) and Araujo et al. (2014) for more methodology details).

$\log (D I N)=3.99+0.35 \times \log (P)+0.75 \times \log (R)$

$5 \log (D I P)=2.72+0.36 \times \log (P)+0.78 \times \log (R)$

where DIN, DIP are the discharged exportation into the coastal region of dissolved inorganic nitrogen ( moles $_{\text {km }}^{-2}$ year $^{-1}$ ) and the discharged exportation into the coastal region of dissolved inorganic phosphorus moles (moles $\mathrm{km}^{-2}$ year $^{-1}$ ); $\mathrm{P}$ is the population density $\left(h a b \mathrm{~km}^{-2}\right)$ and $\mathrm{R}$ is the surface runoff $\left(\mathrm{m}\right.$ year $\left.{ }^{-1}\right)$. The nitrate $\left(\mathrm{NO}_{3}^{-}\right)$and the phosphate $\left(\mathrm{PO}_{4}^{-3}\right)$ concentrations are then calculated using the following formula :

$\left[N O_{3}^{-}\right]=\frac{62.5 \times D I N \times P}{3600 \times 24 \times 365}$

$\left[P O_{4}^{-3}\right]=\frac{45 \times D I P \times P}{3600 \times 24 \times 365}$

where $\left[\mathrm{NO}_{3}^{-}\right]$is the nitrate concentration in moles $\mathrm{m}^{-3}$ and $\left[\mathrm{PO}_{4}^{-3}\right]$ the phosphate concentration in moles $\mathrm{m}^{-3}$ and $\mathrm{Q}$ the river discharge in $m^{-3} s^{-1}$.

We also used numerical outputs data of nitrate, phosphate, iron and chlorophyll concentrations obtained from the Marine Copernicus MERCATOR GREEN (http://marine.copernicus.eu/). The model is forced by the biogeochemical model Pelagic Interaction Scheme for Carbon and Ecosystem Studies: PISCES) (Aumont and Bopp, 2006), gridded at $1^{\circ}$ spatial resolution, and initialized by LEVITUS and the GLobal Ocean Data Analysis Project (GLODAP) climatologies. The rivers discharges are initialized with the climatological datasets of Dai et al. (2009). The MERCATOR GREEN dataset is available from 1998 to 2014.

All the monthly anomalies have been calculated by removing the climatological seasonal cycle, which is the most dominant in the tropical Atlantic (Burls et al., 2011), and calculated over the period 1993-2015, which is the common period of most all the variables at hand. 
Biogeosciences Discuss., https://doi.org/10.5194/bg-2017-346

Manuscript under review for journal Biogeosciences

Discussion started: 20 September 2017

(c) Author(s) 2017. CC BY 4.0 License.

\section{Results}

\subsection{Sea Surface Temperature and climate indices}

Water temperature is one of the most sensitive parameters that influence the Sargassum productivity (Gao and McKGao, 1994). To check for any trends or events specific to the Sargassum blooms years in the tropical Atlantic, the interannual anomalies of

5 SSTs are analyzed (Fig. 1). The spatio-temporal variability of the SST anomalies and the surface wind stress (Praveen Kumar et al., 2013; Servain et al., 2014) from 2009 to 2015 are depicted for the whole Atlantic basin (Fig. 1, top). This figure presents anomalously high positive anomalies of SST (with values greater than $1.5^{\circ} \mathrm{C}$ ) in the whole Atlantic basin and especially in the northwest part of the basin, in 2010 and early 2011. These positive anomalies are associated with a very high positive index of AMO and a strong negative index of the NAO. A cooling trend, especially in the eastern basin, is then observed from 2012. Figure 1 (bottom) presents the interannual variability of SST anomalies in the NERR. The black stars represent the years of Sargassum blooms. A cool period is observed from 1979 to 1995, and from 1996 to 2015 both positive and negative SST anomalies are portrayed. The abnormally high positive anomalies of 2010 (with values of $0.8^{\circ} \mathrm{C}$ ) and the negative SST anomalies from 2012 to 2015 are also depicted.

In order to investigate climatic events that could be linked to the Sargassum blooms, the climate indices AMO and NAO, along with the AMM are presented in Fig. 2. From 1950 to 2015, the analysis of the AMO (Fig. 2a) suggests three major periods: a warm phase from 1950 to 1963, a cool phase from 1964 to 1994 and a second warm phase from 1995 to 2015. Note that AMO is a climate cycle at large time scale that affects the SSTs in the North Atlantic (McCarthy et al., 2015). A positive (respectively negative) phase of AMO is associated with warmer (respectively cooler) SSTs in the North tropical Atlantic. The anomalously high AMO is obtained in 2010 along with the anomalously high negative phase of the NAO (Fig. 2b) (Lefèvre et al., 2013; Servain et al., 2014). The NAO is also a climatic index linked to the direction and magnitude of the westerly winds that control the location of storms in the North Atlantic basin (Hurrel, 2003). A negative NAO index is observed from 2009 to 2011, associated with weak trade winds and warmer SSTs, whereas a positive phase of NAO is observed from 2012 to 2015, associated with strong trade winds and cooler SSTs. The AMM is the dominant source of coupled ocean-atmosphere variability in the tropical Atlantic and linked to rainfall in Northeast Brazil and tropical cyclone development in the North Atlantic (http://www.aoml.noaa.gov/phod/research/tav/tcv/amm/index.php). A positive phase of the AMM is associated with a northward shift of the Atlantic Intertropical Convergence Zone (ITCZ), which causes drought in Northeast Brazil, warmer SSTs and weaker vertical wind shear in the tropical North Atlantic (Foltz et al., 2012). From 2011 to 2012 (respectively 2013 to 2015), a positive phase (respectively a negative phase) of the AMM is observed (Fig. 2c).

\subsection{Rivers discharges and nutrients load}

30 The analysis of the Amazon, Orinoco and Congo rivers discharges (the majors rivers off western and eastern tropical Atlantic) (Araujo et al., 2014) is essential to better understand the origin of the Sargassum recent blooms because of the nutrients load. Figure 3 presents the interannual (Fig. 3a), the climatology (Fig. 3b) and the anomalies of seasonal discharges (Fig. 3c) as inferred from the HYBAM observatory database. The interannual variability of the three discharges (Fig. 3a) shows that the 
Biogeosciences Discuss., https://doi.org/10.5194/bg-2017-346

Manuscript under review for journal Biogeosciences

Discussion started: 20 September 2017

(C) Author(s) 2017. CC BY 4.0 License.

amplitude of the Amazon discharge variability is considerably larger than those of the two other rivers. From 1979 to 2015 , the Amazon River discharge oscillated between the maximum value of $30 \times 10^{4} \mathrm{~m}^{3} \mathrm{~s}^{-1}$, obtained in 2006 and the minimum value of $7 \times 10^{4} \mathrm{~m}^{3} \mathrm{~s}^{-1}$, reached between the end of 2010 and early 2011 . Note that the first Sargassum blooms have been reported in 2011. The Orinoco and the Congo rivers discharges do not present a significant year-to-year variability. The climatological signal (Fig. 3b) indicates that the Sargassum blooms and mass strandings in the tropical Atlantic Ocean, occurred generally during the ascending and the high flow of the Amazon River, i.e. from February to August. Furthermore, Sargassum mass strandings in the West Indies and Carribean mostly occur from February to May (Gower et al., 2013; Wang and Hu, 2016), when the Orinoco River low flow and the descending phase of the Congo River are observed. The mean seasonal anomalies of the Amazon River (Fig. 3c) indicate that during the first year of Sargassum blooms in 2011 and Sargassum maximal spatial coverage amount in 2015 (Wang et al., 2012), the normalized discharge anomalies are not significant, compare to the $50 \%$ of the discharge standard deviation. Only the mean values from July 2013 to December 2014 and July to September 2015 are more than $50 \%$ of the discharge standard deviation.

Sargassum natans and Sargassum fluitans productivity is influenced by nutrients intake, and nitrate and phosphate have been found to enhance these algae's production (Lapointe, 1986; Gao and Nakahara, 1990; Lapointe, 1995; Smetacek and Zingone, 2013; Sissini et al., 2017). But these latter are more nitrate limited than phosphate limiting (Lapointe, 1995). Figure 4 exhibits the interannual variability of nitrate and phosphate fluxes anomalies for the Amazon (Fig. 4a), and the Congo rivers (Fig. 4b). In addition to interannual variability, the mean seasonal anomalies of nitrate flux is also shown for the Amazon and the Congo rivers (Figures 4c-d). These results are obtained from regression models built using 165 water systems worldwide analysis, and DIN and DIP information (Smith et al., 2003; Araujo et al., 2014). Concerning the Amazon River, a clear upward trend is noticeable from 1979 to 2015 for nitrate and phosphate. The Congo River nutrients variabilities also present an upward trend but not pronounced if compared to the Amazon River's one. From 2011 to 2015, the difference between nitrate from Amazon and Congo rivers can reach $20 \mathrm{~kg} \mathrm{~mol} \mathrm{~d}^{-1}$. The continental nutrient load from the Amazon basin during these years is unprecedented. Furthermore, the mean seasonal average for the Amazon River from 2011 evinces the anomalously high values of continental nitrate load during the blooms events. On the contrary, positive anomalies of nitrate fluxes for the Congo River, from 2011 to 2015, are similar to values observed during previous years (2006 to 2010).

In addition to continental nutrients flux from the rivers, Fig. 5 exhibits results from the Copernicus-Marine MERCATOR GREEN products for the mean seasonal anomalies, related to the period 1998-2014: nitrate concentration in the NERR box (Fig. 5a) and in the equatorial upwelling region $\left[2^{\circ} \mathrm{S}-2^{\circ} \mathrm{N} ; 0-20^{\circ} \mathrm{W}\right]$ (Fig. 5b); phosphate concentration in the NERR box (Fig. 5c) and in the equatorial upwelling region (Fig. 5d); iron concentration in the NERR box (Fig. 5e) and chlorophyll concentration in the NERR box (Fig. 5f). Due to the deepening of the thermocline in the west and its shoaling in the eastern basin, the values have been average from $100 \mathrm{~m}$ to the surface for NERR and from $40 \mathrm{~m}$ to the surface for the equatorial region. In the NERR, the nitrate concentration anomalies are negative from 2010 to April-May-June 2012. During the Sargassum blooms events, only the period from the end of 2012 to 2015 evinces high unprecedented anomalies from 1998 to 2015 , with value > $0.4 \mu \mathrm{mol} l^{-1}$. In contrast to the NERR region, the equatorial upwelling region exhibits high anomalies with values up to 1.35 $\mu \mathrm{mol} l^{-1}$ during the 2011 to 2015 year period. Thereby, the limiting nutrient for the Sargassum fluitans and the Sargassum 
Biogeosciences Discuss., https://doi.org/10.5194/bg-2017-346

Manuscript under review for journal Biogeosciences

Discussion started: 20 September 2017

(C) Author(s) 2017. CC BY 4.0 License.

natans show relative high positive anomaly of nitrate concentration with two sources (in the west and in the east) during the recent Sargassum blooms. The same patterns are visible for the phosphate concentrations for both the NERR and the equatorial upwelling region: the years 2011 to 2015 show unprecedented positive anomalies of phosphate in the NERR, with values as high as $0.13 \mu \mathrm{mol} \mathrm{l} \mathrm{l}^{-1}$. Note that the variability of phosphate is usually similar to those of nitrate (Smith et al., 2003). An increase of iron concentration, from the African dust, in the western basin has also been proposed to be a potential cause of the recent Sargassum blooms in the tropical Atlantic (Franks et al., 2014; Oxenford et al., 2015). Nonetheless, Fig. 5e indicates a relative iron decrease from 2011 to 2015. Only the beginning of 2011, the end of 2012 and the beginning of 2013 show positive anomalies of iron. However, these values are not superior to those of the period 2005-2008 when no Sargassum blooms have been reported. From 1998 to 2010, the anomalies of chlorophyll concentration in the NERR are generally negative, then they are positive from July to September 2011 (Fig. 5f). The highest value of $0.034 \mathrm{mg} \mathrm{m}^{-3}$ is reached in July-August-September 2014. Thus, the increase of chlorophyll corresponds to the period of the recent blooms of Sargassum in the tropical Atlantic.

In summary, these results mostly indicate that :

- anomalously high SSTs were present in the western basin, in the NERR in 2010 and during early 2011, when the blooms began to be observed;

- the Amazon River discharge is not directly linked to the blooms and mass strandings events of Sargassum, observed in the tropical Atlantic Ocean since 2011;

- on the contrary, highest values of the Amazon River nutrients inputs, are well reached during the years when blooms were reported from 2011.

\section{Discussions and conclusions}

The potential causes of the recent Sargassum blooms events in the tropical Atlantic Ocean are studied by the analysis of climate or environmental variations that could have generated these unprecedented and repetitive blooms. Indeed, mass strandings of the Sargassum natans and the Sargassum fluitans have been reported along the West Indies, the Caribbean and the West Africa coasts since 2011. These strandings have been shown to also come from a new area of Sargassum concentration, the North Equatorial Recirculation Region of the Atlantic Ocean (NERR) (Gower et al., 2013; Wang and Hu, 2016). Sargassum production, is influenced principally by irradiance, temperature and nutrients (Gao and Nakahara, 1990; Gao and McKGao, 1994). Furthermore, Sargassum natans and Sargassum fluitans productivity is increased by an extra addition of nitrate and phosphate in the coastal waters, by nutrient loads from land (Lapointe, 1986, 1995; Smetacek and Zingone, 2013).

This study presents for the most part, interannual variability of observations and model outputs data of SSTs, climate indices and nutrients inputs (from rivers and equatorial upwelling region) and their potential effects on the Sargassum blooms.

The results of the seasonal anomalies of SST, from 2008 to 2015, indicate that very high positive anomalies have been observed in the whole Atlantic basin in 2010 and especially in the northwest basin and in the NERR region, in 2010 and early 
Biogeosciences Discuss., https://doi.org/10.5194/bg-2017-346

Manuscript under review for journal Biogeosciences

Discussion started: 20 September 2017

(C) Author(s) 2017. CC BY 4.0 License.

2011. The analyses of the climate indices AMO and NAO (Fig. 2) confirm that these high positive anomalies are concurrently related, with strong high positive AMO and negative NAO indices as proposed by Lefèvre et al. (2013) and Servain et al. (2014). This warming of the SST could have been in favor of Sargassum blooms by assuming that the optimum growth temperature for Sargassum natans and Sargassum fluitans has been reached. Note that this optimal Sargassum growth temperature is not well defined. Furthermore, the effect of temperature on Sargassum growth seems to be related to nutrient conditions. Indeed, it has been shown that an increase in temperature, from $23^{\circ} \mathrm{C}$ to $29^{\circ} \mathrm{C}$ has not effect on the palatability of Sargassum filipendula but increases the rate of consumption (O'Connor, 2009; Endo et al., 2013). The growth rate of the Sargassum patens has also been found to be increased indirectly by an increase of temperature within the range of $10^{\circ} \mathrm{C}$ to $30^{\circ} \mathrm{C}$ but this effect only depends on the nutrient availability (Endo et al., 2013). Similar conclusions were made by Talling (2012) for algal growth, which has been found to be affected by light and nutrient conditions. In contrast to 2010 to 2011, negative anomalies of SSTs from 2013 to 2015 were observed in the NERR $<0.75^{\circ} \mathrm{C}$ in average (Fig. 1), while the blooms were still observed with a maximum spatial coverage in 2015. Considering these previous results, further studies in genetic or in biology are needed to determine the optimal temperature for the Sargassum natans and the Sargassum fluitans maximum productivity in different nutrient conditions.

The repetitive and unprecedented peaks in the major climate indices (NAO, AMM, AMO) have also been proposed to have generated these blooms phenomenon (Franks et al., 2014). Figure 2b shows a NAO positive phase from 2012 to 2015 , which may have been related to more cool waters and strong trade winds, more vertical mixing and more subsurface nutrients. Nevertheless, a NAO positive phase with similar values was also observed from 1989 to 1995, but no blooms were reported during these years. Moreover, a NAO negative phase is observed from 2010 to 2011 when the blooms occurred. So, major climate variations in the tropical Atlantic cannot directly explain the recent Sargassum blooms. Note that, the analysis of the ITCZ position, from 1979 to 2015 did not reveal any abnormal event (or significant abnormalities compared to the climatological mean) during the years of Sargassum bloom (not shown).

The study also addresses the relative importance of nutrients for Sargassum natans and Sargassum fluitans growth, principally nitrate and phosphate as they have been identified as limiting nutrients (Lapointe, 1986, 1995; Smetacek and Zingone, 2013). Rivers are important sources of nutrients. The Amazon, the Orinoco and the Congo Rivers are the three major rivers of the tropical Atlantic. The analysis of the Amazon, Orinoco and Congo Rivers discharges, indicates that the volume of water flowing is not the dominant control of the changes in the Sargassum natans and the Sargassum fluitans ecosystem. Indeed, the discharge normalized anomalies are not significant during the first year of Sargassum recent blooms in 2011 and Sargassum maximum spatial coverage amount in 2015 (Wang et al., 2012). Moreover, there was none bloom that has been reported in 2006, year of the maximum discharge for the Amazon River, which is the most important river of the world. Nevertheless, it is important to notice that the blooms and the mass strandings are generally observed during the ascending and high flow of the Amazon River (Gower et al., 2013; Wang and Hu, 2016).

One important point to mention from the present study is that a good agreement is found between the continental inputs of nitrate and phosphate from the Amazon River and the Sargassum blooms. On the contrary, the Congo River nutrients inputs do not significantly increased during the Sargassum blooms. Thus, our results indicate that the increase of nutrients 
Biogeosciences Discuss., https://doi.org/10.5194/bg-2017-346

Manuscript under review for journal Biogeosciences

Discussion started: 20 September 2017

(C) Author(s) 2017. CC BY 4.0 License.

may certainly be linked to the deforestation, the increase of sediments and the continental run-off in the Amazon basin observed these last years. Similar conclusions in the NERR region are also suggested by the MERCATOR GREEN outputs (Fig. 5a,c). The Brazilian government have taken steps to reduce deforestation and its effect (a decelerate trend from 2004 to 2012). But the Amazonian forest deforestation continues and an increase of $29 \%$ in 2015 and 2016 has been reported

5 by the Brazilian Instituto Nacional de Pesquisas Espaciais (INPE: http://www.inpe.br/noticias/noticia.php?CodNoticia=4344; http://www.obt.inpe.br/prodes/index.php). Moreover, note that pollution of groundwater and river water by nitrate and phosphate or eutrophication, which is characterized by an excessive development of the seaweed, is a slow process which has a deferred character. It means that it takes several years for a drop of nitrate to seep into the soil and its way into a river. The effects of deforestation on the continental nitrate and phosphate inputs can be felt years later (Meyer-Reil and Köster, 2000). In addition, eutrophication is also made by excessive agroindustrial and urban activities. It is also important to notice that Brazil has been found to be the biggest consumer of agrotoxics (fertilizers, pesticides and agricultural fertilizers) in the world, by the increase of agroindustrial activities (https://alencontre.org/ameriques/amelat/bresil/bresil-oligopolisation-pollution-etagriculture.html; refer to Correio da Cidadania dated August 15 th 2012). Thereby deforestation, increase of sediments and increase of agroindustrial activities are in favor of nitrate and phosphate pollution in the Amazon River that may have influenced the recent Sargassum blooms. Similar conclusions were reached by Sissini et al. (2017). These authors argued that a possible explanation for the recent blooms may be linked to warmer SSTs in nutrient-enriched oceans conditions induced by continental runoff with agroindustrial and urban origin. Thus, positive SST anomalies observed in 2010-2011 could have induce favorable conditions for Sargassum blooms, then fed by additional nutrients inputs from the Amazon River.

This study also suggests, from very recent numerical results, that the subsurface intake of nutrients in the equatorial upwelling region could also have contributed in the blooms and the mass strandings of the Sargassum blooms (Fig. 5b) in the Atlantic Ocean. However, another datasets need to be analyzed, keeping in mind that there are probably some biases in the vertical velocity of the MERCATOR GREEN, at the equator that could artificially enhance the potential equatorial upwelling effect. Finally, Guerreiro et al. (2017) have reported that African dust could have be a fertilizer for marine phytoplankton in the Atlantic Ocean; further studies are also needed to evaluate the potential impact, even with weaker amount than nutrients, of the iron and the African dust inputs in the NERR.

This work highlights and provides new insights about of the effects of the combined warmer SSTs in 2010 and the increase of nitrate and phosphate continental inputs of the Amazon River due to continental run-off generate by deforestation, agroindustrial and urban source as the one of the main causes of the recent Sargassum blooms in the tropical Atlantic Ocean. Additional datasets and models outputs have to be analyzed in order to continue this investigation.

Acknowledgements. This study is a part of the physical oceanography component of the French Institut de Recherche pour le Développement (IRD/ MEDD) project "Sargasses" and was initiated during a 8 months visit of the $1^{\text {st }}$ author at the Departamento de Oceanografia da Universidade Federal de Pernambuco (DOCEAN/UFPE) in Recife. It has received funding from the Brazilian National Council for Scientific and Technological Development (CNPq) and from IRD through the Laboratoire d'Etudes en Géophysique et Océanographie Spatiales (LE- 
Biogeosciences Discuss., https://doi.org/10.5194/bg-2017-346

Manuscript under review for journal Biogeosciences

Discussion started: 20 September 2017

(c) Author(s) 2017. CC BY 4.0 License.

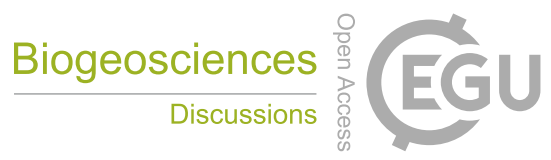

(c) (i)

GOS), UMR 5566 CNES/CNRS/IRD/UPS. The first author would like to acknowledge these or-ganizations. M. A., G. H. and C. N. thank the support of the Brazilian Research Network on Global Climate Change-Rede CLIMA (FINEP grants 01.13.0353-00). Thanks to the authors of data sets made available in free access. The TropFlux data is produced thanks to a collaboration between Laboratoire d'Océanographie: Expérimentation et Approches Numériques (LOCEAN) from Institut Pierre Simon Laplace (IPSL, Paris, France) and National Institute of 5 Oceanography/CSIR (NIO, Goa, India), and supported by the French Institut de Recherche pour le Développement (IRD, France). TropFlux relies on data provided by the ECMWF Re-Analysis interim (ERA-I) and ISCCP projects. The authors also acknowledge the Marine Copernicus Service and Dr Fabrice Hernandez for kindly providing the MERCATOR BIOMER data. Thanks are given to Dr Jacques Servain, Dr Fréderic Ménard and the Mediterranean Institute of Oceanography (MIO) team and also to Dr Pierrick Penven for constructive discussions during this work. This paper also represents a contribution to Project Pólo de Interação para o Desenvolvimento de Estudos Conjuntos em Oceanografia do Atlântico Tropical (PILOTE), CNPq-IRD grant 490289/2013-4. 
Biogeosciences Discuss., https://doi.org/10.5194/bg-2017-346

Manuscript under review for journal Biogeosciences

Discussion started: 20 September 2017

(c) Author(s) 2017. CC BY 4.0 License.

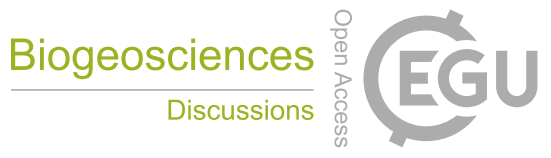

\section{References}

Ang, P. O.: Phenology of Sargassum spp. in Tung Ping Chau Marine Park, Hong Kong SAR, China, J. Appl. Phycol., 18, 403-410, 2006.

Araujo, M., Noriega, C., and Lefèvre, N.: Nutrients and carbon fluxes in the estuaries of major rivers flowing into the tropical Atlantic, Front. Mar. Sci., 1:10, https://doi.org/10.3389/fmars.2014.00010, 2014.

5 Aumont, O. and Bopp, L.: Globalizing results from Ocean in situ iron fertilization studies, Glob. Biogeochem. Cycles, $20,2006$.

Burls, N. J., Reason, C. J. C., Penven, P., and Philander, S. G.: Similarities between the tropical Atlantic seasonal cycle and ENSO: An energetics perspective, J. Geophys. Res., 116, C11 010, https://doi.org/10.1029/2011JC007164, 2011.

Butler, J. N. and Stoner, A. W.: Pelagic Sargassum: has its biomass changed in the last 50 years ? , Deep Sea Research, 31, 1259-1264, https://doi.org/10.1016/0198-0149(84)90061-X, 1984.

Butler, J. N., Morris, B. F., Cadwallader, J., and Stoner, A. W.: Studies of Sargassum and the Sargassum community, 307 pp, Bermuda Biological Station Special Publication 22, 1983.

Carpente, R. C., Hackney, J. M., and Adey, W. H.: Measurements of primary productivity and nitrogenase activity of coral reef algae in a chamber incorporating oscillatory flow, Limnol. Oceanogr., 36, 40-49, 1991.

Chiang, J. C. H. and Vimont, D. J.: Analogous meridional modes of atmosphere-ocean variability in the tropical Pacific and tropical Atlantic,

J. Climate, 17, 4143-4158, 2004.

Chin, M., Diehl, T., Tan, Q., Prospero, J. M., Kahn, R. A., Remer, L. A., Yu, H., Sayer, A. M., Bian, H., Geogdzhayev, I. V., Holben, B. N., Howell, S. G., Huebert, B. J., Hsu, N. C., Kim, D., Kucsera, T. L., Levy, R. C., Mishchenko, M. I., Pan, X., Quinn, P. K., Schuster, G. L., Streets, D. G., Strode, S. A., Torres, O., and Zhao, X.-P.: Multi-decadal aerosol variations from 1980 to 2009 : a perspective from observations and a global model, Atmos. Chem. Phys, 14, 3657-3690, https://doi.org/10.5194/acp-14-3657-2014, 2014.

Dai, A., Qian, T., Trenberth, K. E., and Milliman, J. D.: Changes in continental freshwater discharge from 1948-2004, J. Climate, 22, 2773-2791, 2009.

Endo, H., Suehiro, K., Kinoshita, J., Gao, X., and Agatsuma, Y.: Combined Effects of Temperature and Nutrient Availability on Growth and Phlorotannin Concentration of the Brown Alga Sargassum patens (Fucales; Phaeophyceae), American Journal of Plant Sciences, 4, 14-20, https://doi.org/10.4236/ajps.2013.412A2002, http://www.scirp.org/journal/ajps, 2013.

Evan, A. T., Flamant, C., Gaetani, M., and Guichard, F.: The past, present and future of African dust, Nature, https://doi.org/10.1038/nature17149, 2016.

Foltz, G. R., McPhaden, M. J., and Lumpkin, R.: A strong Atlantic Merional Mode event in 2009: The role of mixed layer dynamics, J. Climate, 25, 363-380, https://doi.org/10.1175/JCLI-D-11-00150.1, 2012.

Franks, J., Johnson, D., and Ko, D.-S.: Pelagic Sargassum; Retention and growth of pelagic sargassum in the North Equatorial Convergence Region of the Atlantic Ocean: hypothesis for examining recent mass strandings of sargassum along Caribbean and West Africa coast, in: Gulf and Caribbean Fisheries Institute Caribbean Sargassum, 2014.

Gao, G. and McKGao, K. R.: Use of macroalgae for marine biomass production and CO2 remediation: a review, J. Appl. Phycol., 6, 45-60, 1994.

Gao, K.: Effects of seawater current speed on the photosynthetic oxygen evolution of Sargassum thunbergii (Phaeophyta), Jpn. J. Phycol., 39, 291-293 (Japanese, with English summary)., 1991.

Gao, K. and Nakahara, H.: Effects of nutrients on the photosynthesis of Sargassum thunbergii, Bot. Mar., 33, 375-383, 1990. 
Biogeosciences Discuss., https://doi.org/10.5194/bg-2017-346

Manuscript under review for journal Biogeosciences

Discussion started: 20 September 2017

(c) Author(s) 2017. CC BY 4.0 License.

Gellenbeck, K. and Chapman, D.: Feasibility of mariculture of the brown seaweed, Sargassum muticum (Phaeo- phyta): Growth and culture conditions, culture methods, alginic acid content and conversion to methane, In Barclay WR, 1986.

Goes, J. I., Gomes, H. d. R., Chekalyuk, A. M., Carpenter, E. J., Montoya, J. P., Coles, V. J., Yager, P. L., Berelson, W. M., Capone, D. G., Foster, R. A., Steinberg, D. K., Subramaniam, A., and Hafez, M. A.: Influence of the Amazon River discharge on the biogeography of phytoplankton communities in the western tropical north Atlantic, Progress in Oceanography, 120, 29-40, http://www.sciencedirect.com/ science/article/pii/S0079661113001237, 2014.

Gower, J. and King, S.: Distribution of floating Sargassum in the Gulf of Mexico and the Atlantic Ocean mapped using MERIS, International Journal of Remote Sensing, 32, 1917-1929, 2011.

Gower, J., Hu, C., Borstad, G., and King, S.: Ocean color satellites show extensive lines of floating Sargassum in the Gulf of Mexico, IEEE Transactions on Geoscience and Remote Sensing, 44, 3619-3625., 44, 3619-3625, 2006.

Gower, J., Young, E., and King, S.: Satellite images suggest a new Sargassum source region in 2011, Remote Sens Lett, 4:8, 764-773, http://dx.doi.org/10.1080/2150704X.2013.796433, 2013.

Guerreiro, C. V., Baumann, K.-H., A, G.-J., Brummer, Fischer, G., Korte, L. F., Merkel, U., Sá, C., de Stigter, H., and Stuut, J.-B. W.: Coccolithophore fluxes in the open tropical North Atlantic: influence of the Amazon river and of Saharan dust deposition, Biogeosciences Discuss., https://doi.org/10.5194/bg-2017-216, 2017.

Guimberteau, M., Ciais, P., Ducharne, A., Boisier, J. P., Aguiar, A. P. D., Biemans, H., De Deurwaerder, H., Galbraith, D., Kruijt, B., Langerwisch, F., Poveda, G., Rammig, A., Rodriguez, D. A., Tejada, G., Thonicke, K., Von Randow, C., Von Randow, R. C. S., Zhang, K., and Verbeeck, H.: Impacts of future deforestation and climate change on the hydrology of the Amazon basin: a multi-model analysis with a new set of land-cover change scenarios, Hydrol. Earth Syst. Sci. Discuss., in review, https://doi.org/10.5194/hess-2016-430, 2016.

Guiry, M. and Guiry, G.: AlgaeBase: world-wide electronic publication, Galway: National University of Ireland. Electronic Database accessible at http://www.algaebase.org/ . Searched on 10 April 2012., 2011.

Hernandez, F. J.: Sargassum in the northern Gulf of Mexico, http://www.marine.usf.edu/conferences/fio/NSTC-SOST-PI-2011/documents/ LMR/Hernandez_LMR.pdf, 2011.

Hsu, N. C., Gautam, R., Sayer, A. M.and Bettenhausen, C., Li, C., Jeong, M. J., Tsay, S.-C., and Holben, B. N.: Global and regional trends of aerosol optical depth over land and ocean using SeaWiFS measurements from 1997 to 2010, Atmos. Chem. Phys., 12, 8037-8053, https://doi.org/10.5194/acp-12-8037-2012, 2012.

Hu, C., Hardy, R., and Ruder, E., e. a.: Sargassum coverage in the northeastern Gulf of Mexico during 2010 from Landsat and airborne observations: Implications for the Deepwater Horizon oil spill, Marine Pollution Bulletin, 107, 15-21, https://doi.org/10.1016/j.marpolbul.2016.04.045, 2016.

Hurrel, J. W.: The North Atlantic Oscillation: Climatic Significance and Environmental Impact, American Geophysical Union, https://doi.org/ISBN 9780875909943, 2003.

Hurrell, J. and for Atmospheric Research Staff (Eds), N. C.: The Climate Data Guide: Hurrell North Atlantic Oscillation (NAO) Index (station-based), Retrievedfromhttps://climatedataguide.ucar.edu/climate-data/hurrell-north-atlantic-oscillation-nao-index-station-based, 2017.

35 Johnson, D. R., Ko, D. S., Franks, J. S., Moreno, P., and Sanchez-Rubio, G.: The Sargassum invasion of the Eastern Caribbean and dynamics of the Equatorial North Atlantic, in: Proceedings of the 65th Annual Gulf and Caribbean Fisheries Institute Conference, pp. 102-103, 2013. 
Biogeosciences Discuss., https://doi.org/10.5194/bg-2017-346

Manuscript under review for journal Biogeosciences

Discussion started: 20 September 2017

(c) Author(s) 2017. CC BY 4.0 License.

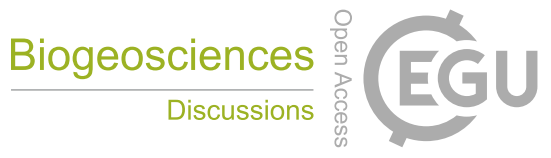

(c) (i)

King, W.: Life is Controlled by the Limiting Nutrient, http://web.colby.edu/colbyatsea/2011/02/01/ life-is-controlled-by-the-limiting-nutrient/, 2011.

Lapointe, B. E.: Phosphorus-limited photosynthesis and growth of Sargassum natans and Sargassum fluitans (Phaeophyceae) in the western North Atlantic, Deep Sea Res., 33, 391-399, 1986.

5 Lapointe, B. E.: A comparison of nutrient-limited productivity in Sargassum natans from neritic vs. oceanic waters of the western North Atlantic Ocean, Limnology and Oceanography, 40(3), 625-633, 1995.

Lefèvre, N., Caniaux, G., Janicot, S., and Gueye, A. K.: Increased $\mathrm{CO}_{2}$ outgassing in February-May 2010 in the tropical Atlantic following the 2009 Pacific El Niño, J.Geophys. Res., 118, 1-13, https://doi.org/10.1002/jgrc.20107, 2013.

Mazéas, F.: Note Sargasses, http://www.guadeloupe.developpement-durable.gouv.fr/IMG/pdf/Note_DEAL_sur_description_et_ explications_des_echouages_Dec2014-MAJ_13aout2015.pdf, 2014.

McCarthy, G. D., Haigh, I. D., Hirschi, J. J. M., Grist, J. P., and Smeed, D. A.: Ocean impact on decadal Atlantic climate variability revealed by sea-level observations, Nature, 521, 508-510, https://doi.org/10.1038/nature14491, 2015.

Meybeck, M.: Carbon, nitrogen and phosphorus transport by world rivers, Am. J. Sci., 282, 401-450, https://doi.org/10.2475/ajs.282.4.401, 1982.

Meybeck, M. and Ragu, A.: Presenting the GEMS-GLORI, a compendium of world river discharge to the oceans, Ass. Hydrol. Sci. Publ., 243, 3-14, 1997.

Meyer-Reil, L.-A. and Köster, M.: Eutrophication of Marine Waters: Effects on Benthic Microbial Communities, Marine Poll. Bull., 41, 255-263, 2000 .

O’Connor, M. I.: Warming Strengthens an Herbivore- Plant Interaction, vol. 90, Ecology, https://doi.org/10.1890/08-0034.1, 2009.

Oxenford, H. A., Franks, J., and Johnson, D.: Facing the threat of Sargassum seaweed, in: Symposium: Challenges, dialogue \& cooperation towards Sustainability of the Caribbean Sea, 2015.

Oyesiku, O. O. and Egunyomi, A.: Identification and chemical studies of pelagic masses of Sargassum natans (Linnaeus) Gaillon and S. fluitans (Borgessen) Borgesen (brown algae), found offshore in Ondo State, Nigeria, African Journal of Biotechnology, $13(10), 2014$.

Praveen Kumar, B., Vialard, J., Lengaigne, M., Murty, V. S. N., McPhaden, M. J., Cronin, M. F., Pinsard, F., and Reddy, K. G.: TropFlux: Air-Sea Fluxes for the Global Tropical Oceans-Description and evaluation, Clim. Dyn., 8, 1521-1543, https://doi.org/0.1007/s00382-0111115-0, 2013.

Prospero, J. M., Collard, F.-X., Molinié, J., and Jeannot, A.: Characterizing the annual cycle of African dust transport to the Caribbean Basin and South America and its impact on the environment and air quality, Global Biogeochem. Cycles, 29, 757-773, https://doi.org/10.1002/2013GB004802, 2014.

Ridley, D. A., Heald, C. L., and Prospero, J. M.: What controls the recent changes in African mineral dust aerosol across the Atlantic?, Atmos. Chem. Phys., 14, 5735-5747, https://doi.org/10.5194/acp-14-5735-2014, www.atmos-chem-phys.net/14/5735/2014/, 2014.

Sankaré, Y., Komoé, K., Aka, K. S., and Fofié, N'guessan Bra Yvette ad Bamba, A.: Répartition et abondance des sargasses Sargassum natans et Sargassum fluitans (Sargassaceae, Fucales) dans les eaux marines ivoiriennes (Afrique de l'Ouest), Int. J. Biol. Chem. Sci., 10(4), 1853-1864, 2016.

Scheuvens, D., Schütz, L., Kandler, K., Ebert, M., and Weinbruch, S.: Bulk composition of northern African dust and its source sedimentsA compilation, Earth-Science Reviews, 116, 170-194, http://www.sciencedirect.com/science/article/pii/S001282521200102X, 2013.

Servain, J., Caniaux, G., Kouadio, Y. K., McPhaden, M. J., and Araujo, M.: Recent climatic trends in the tropical Atlantic, Clim. Dyn., 43, 3071-3089, https://doi.org/10.1007/s00382-014-2168-7, 2014. 
Biogeosciences Discuss., https://doi.org/10.5194/bg-2017-346

Manuscript under review for journal Biogeosciences

Discussion started: 20 September 2017

(c) Author(s) 2017. CC BY 4.0 License.

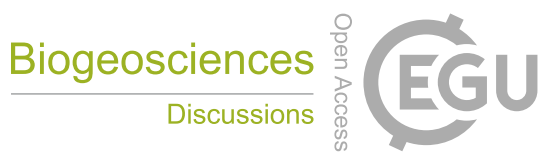

(c) (i)

Sfriso, A. and Facca, C.: Annual growth and environmental relation- ships of the invasive species Sargassum muticum and Undaria pinnatifida in the lagoon of Venice, Estuar. Coast. Shelf S, 129, 162-172, 2013.

Sissini, M. N., Barreto, M. B. B. D. B., Szèchy, M. T. M., Lucena, M. B. D., Oliveira, M. C., Gower, J., Bastos, G. L. E. D. O., Milstein, D., and al.: The floating Sargassum (Phaeophyceae) of the South Atlantic Ocean- likely scenarios, Phycologia, 56 (3), $321-328,2017$.

5 Smetacek, V. and Zingone, A.: Green and golden seaweed tides on the rise, Nature, 504(7478), 84-88, 2013.

Smith, S. V., Swaney, D. P., Talaue-McManus, L., Bartley, J. D., Sandhei, P. T., McLaughlin, C. J., and et al.: Humans, hydrology, and the distribution of inorganic nutrient loading to the Ocean, Bioscience, 53, 235-245, https://doi.org/10.1641/0006-3568(2003)053, 2003.

Swap, R., Garstang, M., Greco, S., Talbot, R., and Kallberg, P.: Saharan dust in the Amazon Basin, Tellus, 44B, 133-149, 1992.

Szèchy, M. T. M., Guedes, P. M., Baeta-Neves, M. H., and Oliveira, E.: Verification of Sargassum natans (Linnaeus) Gaillon (Heterokontophyta: Phaeophyceae) from the Sargasso Sea off the coast of Brazil, western Atlantic Ocean, Check List, 8(4), 638-641, 2012.

Talling, J.: Temperature Increase-An Uncertain Stimulant of Algal Growth and Primary Production in Fresh Waters, Freshwater Biological Association, 5(2), :73-84, https://doi.org/10.1608/FRJ-5.2.471, http://www.bioone.org/doi/full/10.1608/FRJ-5.2.471, 2012.

Trenberth, K., Zhang, R., and for Atmospheric Research Staff (Eds), N. C.: The Climate Data Guide: Atlantic Multi-decadal Oscillation (AMO), Retrievedfromhttps://climatedataguide.ucar.edu/climate-data/atlantic-multi-decadal-oscillation-amo., 2017.

15 Wang, C., Dong, S., Evan, A. T., Foltz, G. R., and Lee, S.-K.: Multidecadal Covariability of North Atlantic Sea Surface Temperature, African Dust, Sahel Rainfall, and Atlantic Hurricanes, 25, https://doi.org/http://dx.doi.org/10.1175/JCLI-D-11-00413.1, 2012.

Wang, M. and Hu, C.: Mapping and quantifying Sargassum distribution and coverage in the Central West Atlantic using MODIS observations, Remote Sens. Environ., 183, 350-367, http://www.sciencedirect.com/science/article/pii/S0034425716301833, 2016.

Wang, M. and Hu, C.: Predicting Sargassum blooms in the Caribbean Sea from MODIS observations, Geophys. Res. Lett., 44, 3265-3273, https://doi.org/10.1002/2017GL072932, 2017.

Xu, Z., Gao, G., Xu, J., and Wu, H.: Physiological response of a golden tide alga (Sargassum muticum) to the interaction of ocean acidification and phosphorus enrichment, Biogeosciences, 14, 671-681, 2017.

Yu, H. and al.: The fertilizing role of African dust in the Amazon rainforest: A first multiyear assessment based on data from Cloud-Aerosol Lidar and Infrared Pathfinder Satellite Observations, Geophys. Res. Lett., 42, https://doi.org/10.1002/2015GL06304, 2015. 
Biogeosciences Discuss., https://doi.org/10.5194/bg-2017-346

Manuscript under review for journal Biogeosciences

Discussion started: 20 September 2017

(c) Author(s) 2017. CC BY 4.0 License.

(c) (1)
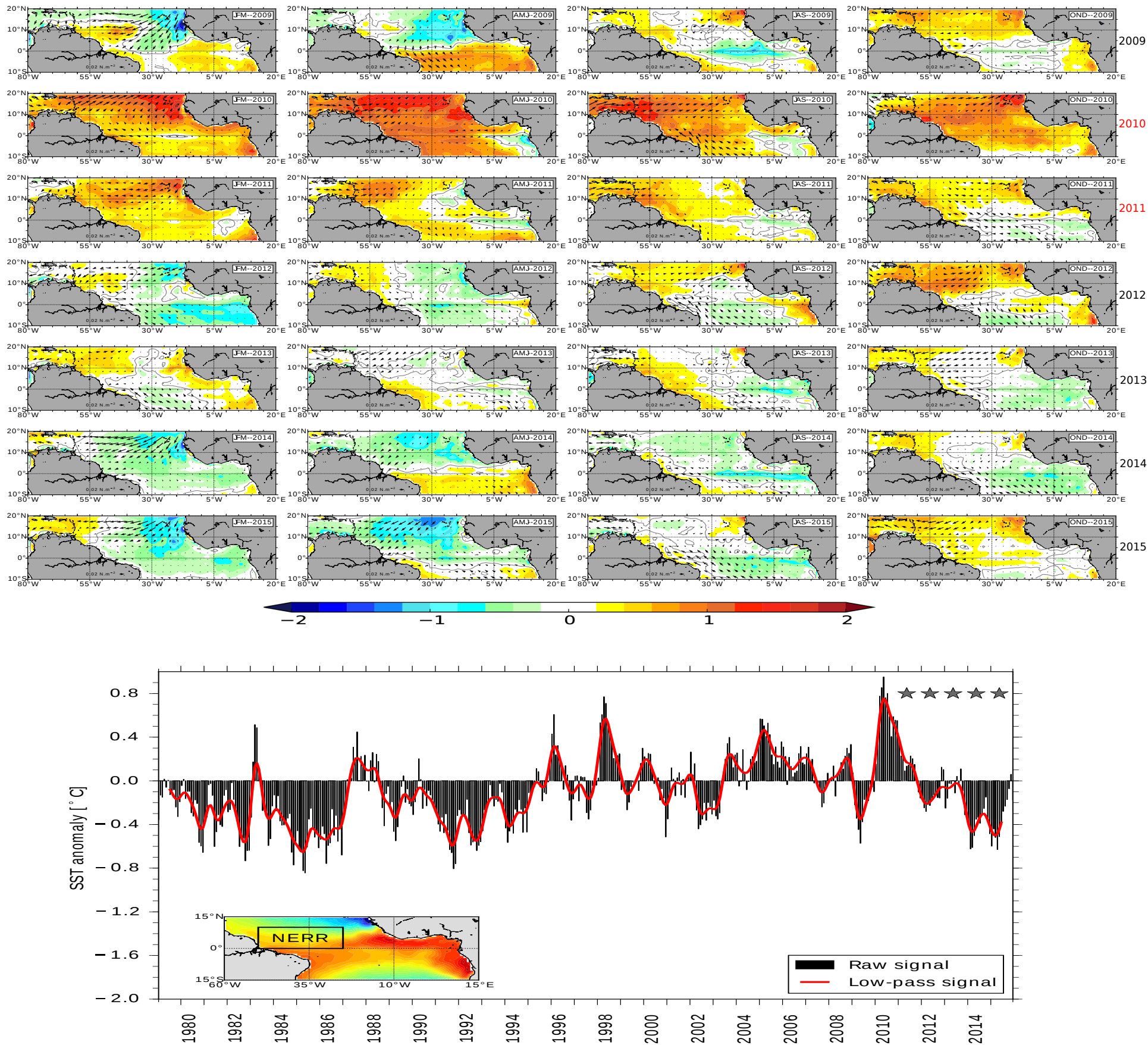

Figure 1. Upper panel: Spatial distributions of seasonal SST $\left[{ }^{\circ} \mathrm{C}\right]$ and wind stress direction anomalies $\left[N \mathrm{~m}^{-2}\right]$ from 2009 to 2015 . The anomalies are related to the period 1993-2015 (per three months periods). The zero isotherm is represented in gray line. Lower panel: Interannual SST anomalies [ ${ }^{\circ} \mathrm{C}$ ], from the TropFlux dataset, related to the period 1993 to 2015 , in the box NERR $\left[0^{\circ}-10^{\circ} \mathrm{N} ; 50^{\circ}-10^{\circ} \mathrm{W}\right.$ ] from 1979 to 2015 . The black stars represent the years of Sargassum blooms. 
Biogeosciences Discuss., https://doi.org/10.5194/bg-2017-346

Manuscript under review for journal Biogeosciences

Discussion started: 20 September 2017

(c) Author(s) 2017. CC BY 4.0 License.

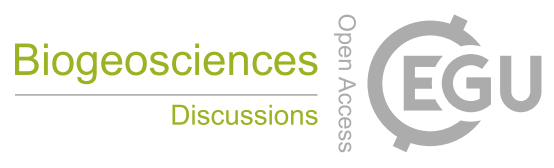

(c) (i)
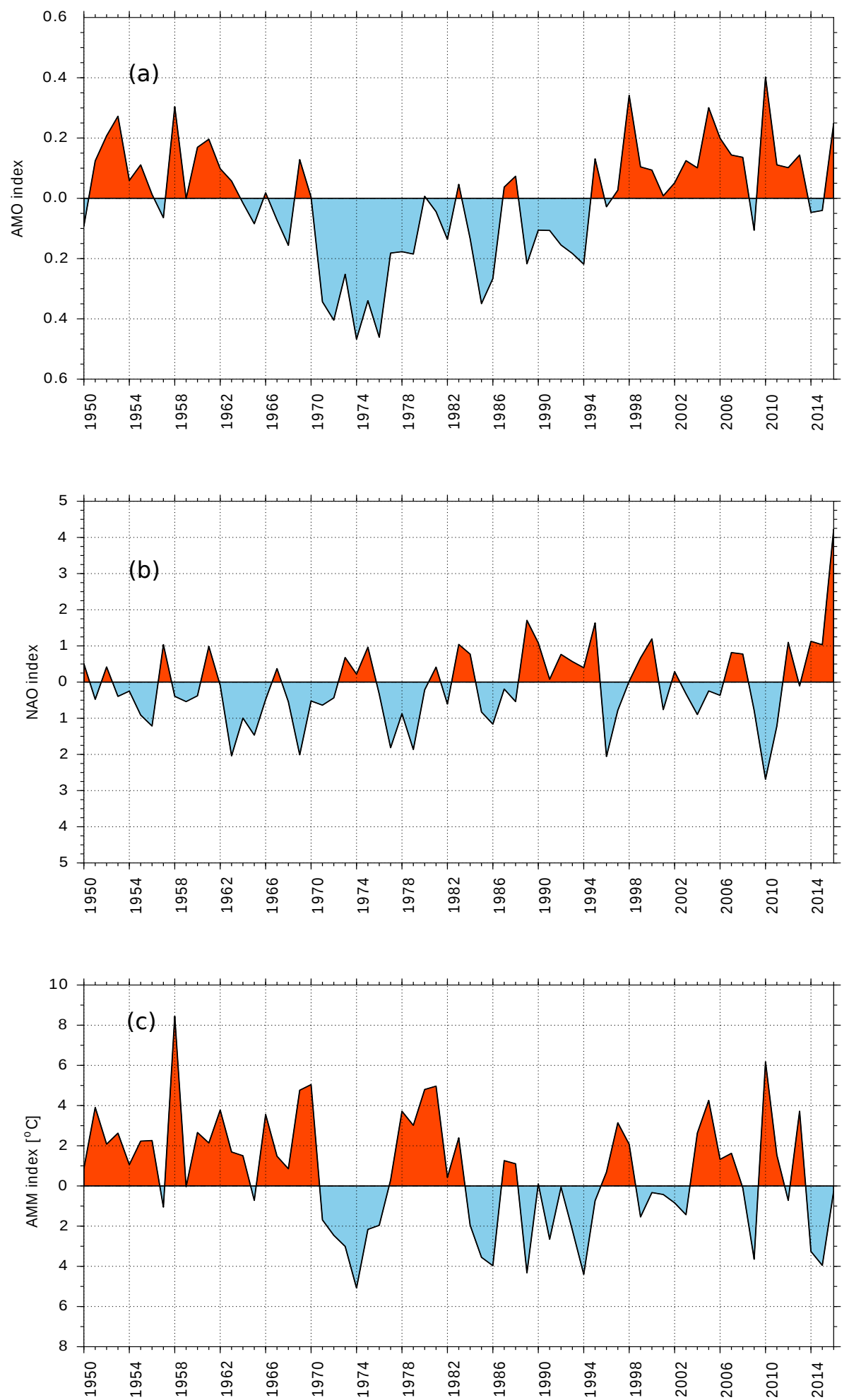

Figure 2. Climate indices from 1950 to 2016: AMO index average value from March to May (a) [source:https://www.esrl.noaa.gov], NAO index average value from December to February (b) [source:https://www.esrl.noaa.gov] and AMM index [source: University Wisconsin using the NCEP SST] (c). 
Biogeosciences Discuss., https://doi.org/10.5194/bg-2017-346

Manuscript under review for journal Biogeosciences

Discussion started: 20 September 2017

(c) Author(s) 2017. CC BY 4.0 License.

(c) (1)
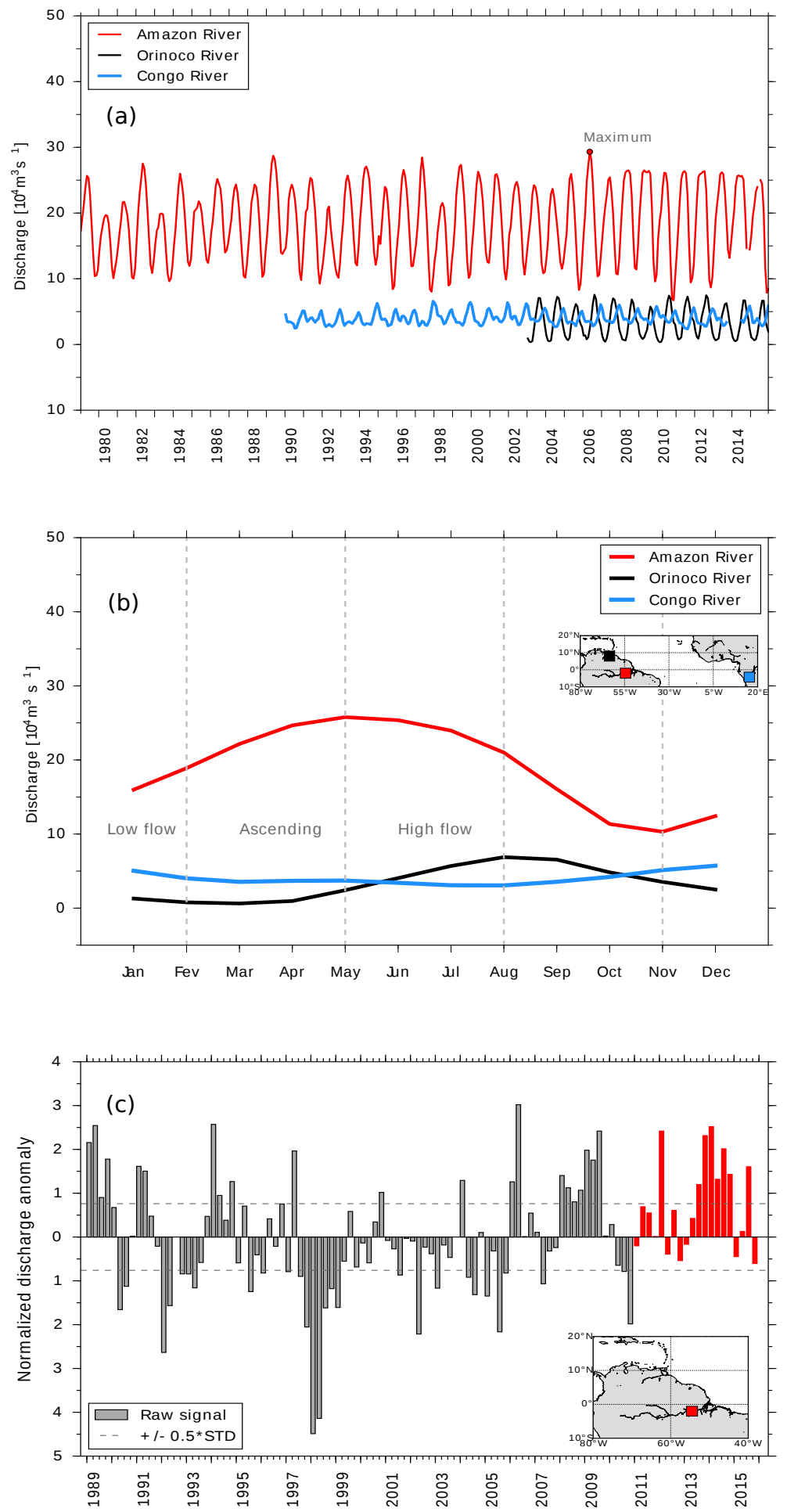

Figure 3. Rivers discharge anomalies $\left[\mathrm{m}^{3} \mathrm{~s}^{-1}\right.$ ] for Amazon, Orinoco and Congo rivers: interannual (a), climatology (b) and mean seasonal value (only for the Amazon River, c). The anomalies are related to the period 1993-2015, from HYBAM dataset. The mean seasonal value during the Sargassum blooms events are represented in red (c). The dotted grey lines depict $50 \%$ of the standard deviation. 
Biogeosciences Discuss., https://doi.org/10.5194/bg-2017-346

Manuscript under review for journal Biogeosciences

Discussion started: 20 September 2017

(c) Author(s) 2017. CC BY 4.0 License.

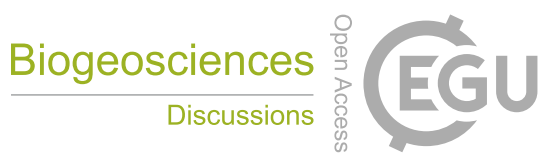

(c) (i)
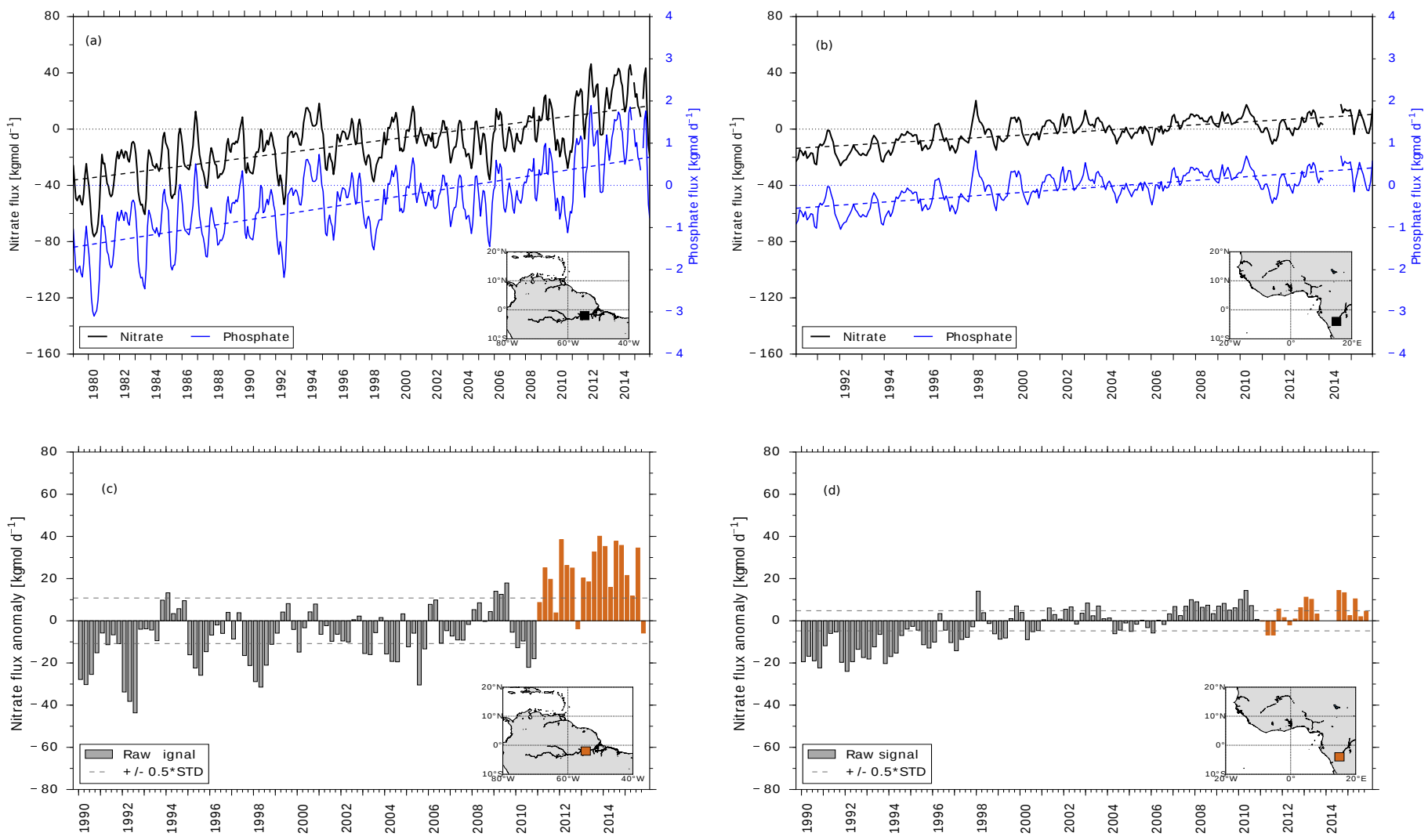

Figure 4. Continental nutrients load flux anomalies $\left[\mathrm{kg} \mathrm{mol} \mathrm{d}^{-1}\right]$, related to the period 1993-2015: nitrate and phosphate from the Amazon River (a) and the Congo River (b); mean seasonal nitrate for the Amazon (c) and for the Congo (d) rivers. The mean seasonal value during the Sargassum blooms events are represented in brown (c, d). 
Biogeosciences Discuss., https://doi.org/10.5194/bg-2017-346

Manuscript under review for journal Biogeosciences

Discussion started: 20 September 2017

(c) Author(s) 2017. CC BY 4.0 License.
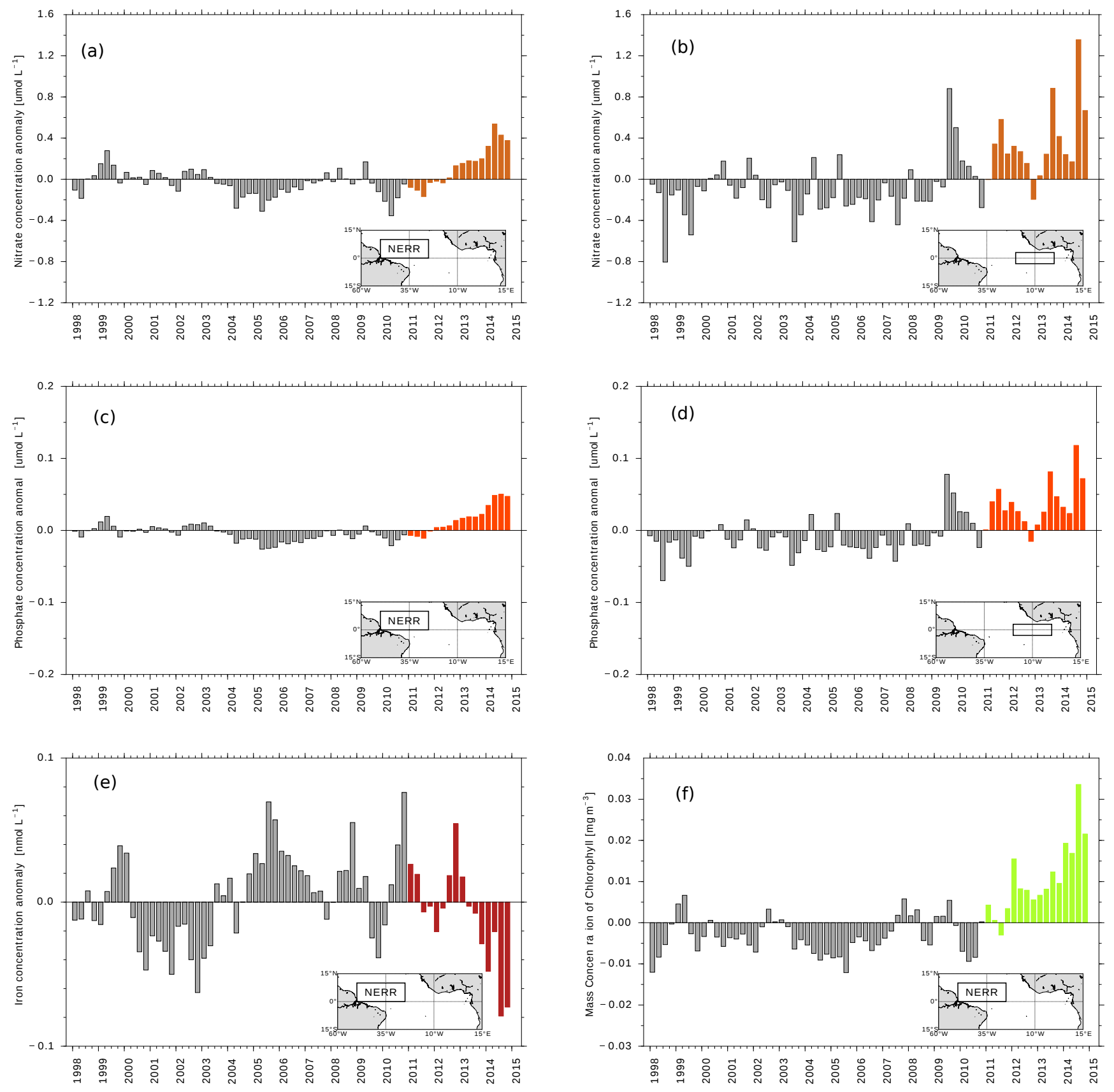

Figure 5. Upper and middle panels: Mean seasonal anomalies of nitrate concentration $\left[\mu m o l l^{-1}\right]$ in the box NERR $\left[0^{\circ}-10^{\circ} \mathrm{N} ; 50^{\circ}-10^{\circ} \mathrm{W}\right]$ (a) and in equatorial upwelling region $\left[2^{\circ} \mathrm{S}-2^{\circ} \mathrm{N} ; 0^{\circ}-20^{\circ} \mathrm{W}\right](\mathrm{b})$. Mean seasonal anomalies of phosphate concentration $\left[\mu m o l l^{-1}\right]$ in the box NERR (c) and in equatorial upwelling region (d). The nitrate and the phosphate concentration have been average over $100 \mathrm{~m}$ (a,c) and $40 m$ for (b,d). Lower panels: Mean seasonal anomalies of iron concentration [ $\mathrm{nmol} \mathrm{l}^{-1}$ ] in the box NERR (e) and mean seasonal anomalies of chlorophyll concentration $\left[\mathrm{mg} \mathrm{m}^{-3}\right.$ ] in the box NERR (f) from the Marine Copernicus MERCATOR GREEN products. The iron and the chlorophyll concentration have been average over $100 \mathrm{~m}$ in the box NERR (e,f). The mean seasonal value during the Sargassum blooms events are represented in chocolate (a,b), in orange (c,d) in red (e) and in green (f). The anomalies are related to the period $1998-2014$. 